\title{
IMPACT OF VERTICAL AND HORIZONTAL FORCES ON THE SEAM IN THE TECHNOLOGICAL PROCESS OF SEWING KNIT FABRICS
}

\author{
Blaženka Brlobašić Šajatović ${ }^{1}$, Bajro Bolić $^{2 *}$, Slavenka Petrak ${ }^{1}$ \\ ${ }^{1}$ University of Zagreb, Faculty of Textile Technology, Department of Clothing Technology, Zagreb, Croatia \\ 2University of Bihać, Faculty of Technical Engineering, Bihać, Bosnia and Herzegovina \\ e-mail: blazenka.brlobasic@ttf.hr
}

\begin{abstract}
:
The aim of this study was to determine the increase in vertical and horizontal forces of the presser foot on the seam during the technological process of sewing knit fabrics. The research was performed on three types of knit fabrics: double jersey (rib one plus one), interlock knit fabric, and bleached interlock knit fabric. In order to meet the criterion of seam quality, it is necessary to adjust the above-mentioned parameters optimally. Depending on the type of the knit fabric, the values of the investigated forces change, and by increasing the number of layers and the sewing speed, the force values increase.
\end{abstract}

\section{Keywords:}

knit fabric, vertical forces, horizontal forces, seam quality

\section{Introduction}

The basic requirement for high-quality seam is that the material during the technological process of sewing moves along the defined length in order to achieve a uniform stitch length. It is only possible to move the work piece when the needle is not in the material, unless needle feed is used. The feed and presser foot of the sewing machine act differently on the work piece, depending on surface characteristics, thickness of the sewn material, stretch, and seam direction. This results in a variety of movements of the work piece that affect the deviation and change in the stitch length. Feed conditions of the work piece affect stitch length stability to a great extent. These conditions depend on the equipment being used as well as on the properties of the fabrics to be sewn. With reference to the equipment first and foremost, the system of work piece feed, accuracy of defining stitch length, and sewing speed are meant. The most important parameters of the work piece feed are vertical forces of the presser foot as well as horizontal forces occurring between the work piece and the feed system. Late detection of inadequate feed and parameters affecting seam quality cause manufacturing errors. Introducing the "online" seam quality monitoring system just in time makes it possible to detect seam faults, and in this way, the manufacturing process will meet quality requirements [1]. Besides feeding the work piece, the other significant factors for high-quality seam are penetration force of the sewing needle, selection and tension of the sewing thread, sewing needle size, and needle point as well as other variables that directly or indirectly affect the quality of the finished product. Correction of certain parameters affects the quality of the seam which is one of the basic requirements for a quality product [2-4].

\section{Materials used for investigation and methods}

Three types of knit fabrics were used to perform the experimental part of examining horizontal and vertical forces acting on the presser foot during the fabric feed in the sewing process:

- double jersey (rib one plus one),

- interlock knit fabric and

- bleached interlock knit fabric.

To make these knit fabric samples, single cotton yarns were used. The plain double knit fabric was made from 20-tex yarns, the interlock knit fabric was made from 22-tex yarns, and the bleached interlock knit fabric was made from 16-tex yarns whose parameters are listed in Table 1. The basic parameters of the cotton yarns that were used to make the knit fabrics are listed in Table 2.

To examine horizontal and vertical forces acting on the presser foot in the process of sewing knit fabrics, a sewing thread made of $100 \%$ PES filaments with a fineness of 13 tex $\times 2$ tex was used (Table 3).

To examine horizontal and vertical forces acting on the presser foot in the sewing process of knit fabrics, a needle designated $\mathrm{Nm} 70$ with light ball point, system SES, was used, which does not damage the threads when penetrating the knit fabric, but displaces them to the side [5]. Tests were performed on knit fabric samples of size $25 \mathrm{~cm} \times 25 \mathrm{~cm}$, and two and three knit fabric plies were sewn with characteristic seams according to ISO 4916, using sewing speeds of 3,000 and 4,000 stitches/ 
Table 1. Basic parameters of the analyzed knit fabrics

\begin{tabular}{|c|c|c|c|c|c|c|c|c|c|c|c|c|}
\hline \multirow{3}{*}{$\begin{array}{l}\text { Parameters of the } \\
\text { fabric structure }\end{array}$} & \multicolumn{12}{|c|}{ Sets of knit fabrics } \\
\hline & \multicolumn{4}{|c|}{ Double jersey } & \multicolumn{4}{|c|}{ Interlock } & \multicolumn{4}{|c|}{ Bleached interlock } \\
\hline & $\mathbf{n}$ & $\mathbf{x}$ & $\mathbf{s}$ & CV & $\mathbf{n}$ & $\mathbf{x}$ & s & CV & $\mathbf{n}$ & $\mathbf{x}$ & $\mathbf{s}$ & CV \\
\hline Dh, stitches/cm & 10 & 10.6 & 0.39 & 3.72 & 10 & 12.5 & 0.41 & 3.27 & 10 & 14.65 & 0.41 & 2.81 \\
\hline Dv, stitches/cm & 10 & 15.6 & 0.44 & 2.81 & 10 & 11.25 & 0.42 & 3.78 & 10 & 11.6 & 0.46 & 3.96 \\
\hline$C_{p b}=\mathrm{Dh} / \mathrm{Dv}$ & & 0.68 & & & & 1.11 & & & & 1.26 & & \\
\hline 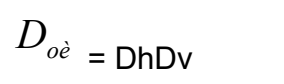 & & 165 & & & & 141 & & & & 169 & & \\
\hline $\mathrm{A}, \mathrm{mm}$ & & 0.85 & & & & 0.92 & & & & 0.80 & & \\
\hline $\mathrm{B}, \mathrm{mm}$ & & 0.70 & & & & 0.79 & & & & 0.70 & & \\
\hline $\mathrm{Dp}, \mathrm{mm}$ & 10 & 0.70 & 0.01 & 0.25 & 10 & 0.90 & 0.14 & 1.58 & 10 & 0.64 & 0.01 & 1.73 \\
\hline $\mathrm{I}_{\mathrm{e}}, \mathrm{mm}$ & 10 & 3.40 & 0.18 & 5.41 & 10 & 4.18 & 0.17 & 4.04 & 10 & 2.82 & 0.16 & 5.74 \\
\hline $\mathrm{Lp}, \mathrm{mm} / \mathrm{cm}^{2}$ & & 552 & & & & 582 & & & & 478 & & \\
\hline$m_{p}, \mathrm{~g} / \mathrm{m}^{2}$ & 10 & 188 & 4.27 & 2.26 & 10 & 230 & 9.88 & 4.29 & 10 & 188 & 5.35 & 2.84 \\
\hline
\end{tabular}

Table 2. Properties of the cotton yarns used to make the knit fabrics used

\begin{tabular}{|c|c|c|c|c|c|c|c|c|c|c|c|c|}
\hline \multirow{3}{*}{ Yarn parameters } & \multicolumn{12}{|c|}{ Intended use of the knit fabrics } \\
\hline & \multicolumn{4}{|c|}{$\begin{array}{l}\text { Production of plain double } \\
\text { jersey (rib one plus one) }\end{array}$} & \multicolumn{4}{|c|}{$\begin{array}{l}\text { Production of rib interlock } \\
\text { knit fabric }\end{array}$} & \multicolumn{4}{|c|}{$\begin{array}{l}\text { Production of bleached } \\
\text { interlock knit fabric }\end{array}$} \\
\hline & $\mathbf{n}$ & $\mathbf{x}$ & $\mathbf{s}$ & CV & $\mathbf{n}$ & $\mathbf{x}$ & $\mathbf{s}$ & CV & $\mathbf{n}$ & $\mathbf{x}$ & $\mathbf{s}$ & CV \\
\hline$T_{t}$, tex & 30 & 19.9 & 0.5 & 2.6 & 30 & 22.1 & 0.5 & 2.6 & 30 & 16.2 & 0.5 & 2.3 \\
\hline $\mathrm{U}, \mathrm{u} / \mathrm{m}$ & 30 & 740 & 42 & 5.6 & 30 & 730 & 42 & 5.6 & 30 & 720 & 33 & 4.7 \\
\hline $\mathrm{Fp}, \mathrm{cN}$ & 30 & 310 & 9.4 & 3.1 & 30 & 300 & 9.4 & 3.1 & 30 & 280 & 8.2 & 2.9 \\
\hline$I_{p}, \%$ & 30 & 5.2 & 0.3 & 4.9 & 30 & 5.1 & 0.3 & 4.9 & 30 & 5.1 & 0.2 & 4.5 \\
\hline$\sigma, \mathrm{cN} / \mathrm{tex}$ & & 15.3 & & & & 15.1 & & & & 13.9 & & \\
\hline $\mathrm{d}_{\mathrm{p}}, \mathrm{mm}$ & & 0.2 & & & & 0.2 & & & & 0.2 & & \\
\hline $\mathrm{Dm} / 1000 \mathrm{~m}$ & & 11 & & & & 10 & & & & 15 & & \\
\hline $\mathrm{Tm} / 1000 \mathrm{~m}$ & & 2 & & & & 1 & & & & 3 & & \\
\hline $\mathrm{Z} / 1000 \mathrm{~m}$ & & 40 & & & & 40 & & & & 30 & & \\
\hline Uster, \% & & 11.4 & & & & 11.3 & & & & 10.1 & & \\
\hline
\end{tabular}

Table 3. Mean values of the basic properties of the used sewing thread

\begin{tabular}{|c|c|c|c|c|c|c|c|c|}
\hline $\begin{array}{l}\text { Thread } \\
\text { count } \\
\text { [tex ] }\end{array}$ & $\begin{array}{c}\text { CV of thread } \\
\text { count } \\
{[\%]}\end{array}$ & $\begin{array}{c}\text { Breaking } \\
\text { force } \\
{[\mathrm{cN}]}\end{array}$ & $\begin{array}{c}\text { CV of } \\
\text { breaking force } \\
{[\%]}\end{array}$ & $\begin{array}{l}\text { Strength } \\
{\left[\mathrm{cN} \mathrm{tex}^{-1}\right]}\end{array}$ & $\begin{array}{c}\text { Elongation } \\
\text { at break } \\
{[\%]}\end{array}$ & $\begin{array}{c}\text { CV of elongation } \\
\text { at break } \\
{[\%]}\end{array}$ & $\begin{array}{l}\text { Twist } \\
\text { level } \\
{\left[\mathrm{m}^{-1}\right]}\end{array}$ & $\begin{array}{c}\text { CV of } \\
\text { twist level } \\
{[\%]}\end{array}$ \\
\hline $13 \times 2$ & 0.70 & 1,150 & 1.58 & 44.2 & 18.00 & 5.20 & 1,085 & 3.00 \\
\hline
\end{tabular}


min, respectively. The tests were carried out using a measuring system that allows the measurement of the penetration force of the sewing needle, the tension force of the thread, and the horizontal and vertical forces of the presser foot of the sewing machine. This measurement system includes a universal double lockstitch Pfaff 483 machine with sewing speed up to 6,000 stitches/min, impulse counter, signal line, manual control, analog-to-digital converter, screen, graphic printer, analog filter, signal amplifier, sensor for needle penetration force, sensor for thread tension force, presser foot, horizontal force sensor for the presser foot, and vertical force sensor for the presser foot.

\subsection{Analysis of forces during the fabric feed}

The parameters of the technological process of sewing knit fabrics (sewing speed, presser foot force) require mutual adjustment to avoid the uncontrolled movement of the work piece, which would allow the formation of a symmetrical seam without causing a damage to the knit fabric during sewing. The vertical pressure of the presser foot on the work piece is determined by adjusting the presser bar to which the foot is fastened and adjustable. This action together with the feed system generates horizontal and vertical force on the drop feed. The interaction of the feed mechanism, the throat plate, and the presser foot enables the feed of the work piece; it depends on the thickness, structure, stretch of the work piece, and the sewing direction. An increase in vertical and horizontal force increases friction, which is the reason why it is necessary to optimize presser foot force in order to achieve the optimum fabric feed. Presser foot force is adjusted by the contact of the feed mechanism with presser foot. This contact effect increases when sewing speeds are higher. The total interaction of the system, needle bar, presser foot, feed system, and work piece, generates the clamping force as a result of oscillation, which makes the work piece feed difficult [6]. Sewing would be impossible without the appropriate feed and the appropriate force of the presser foot. If the presser foot force is too small, it causes an uncontrolled movement of the work piece, and if the sewing speed is increased, feed pucker occurs in the lower ply of the work piece, while too high a presser foot force causes damages to the work piece, especially on delicate and fine materials such as knit fabrics. Shear force or horizontal force generates the actual feed of the sewing material. The feed system [7] generates this force. Contrary to shear force, compressive force or vertical force coming from the bottom of the presser foot acts over the sewing material.

\subsection{Dynamic model of vertical movement}

The vertical movement of the presser foot, the spring, and the fabric and their parameters in the sewing process require proper adjustment within the given limits. The dynamical model

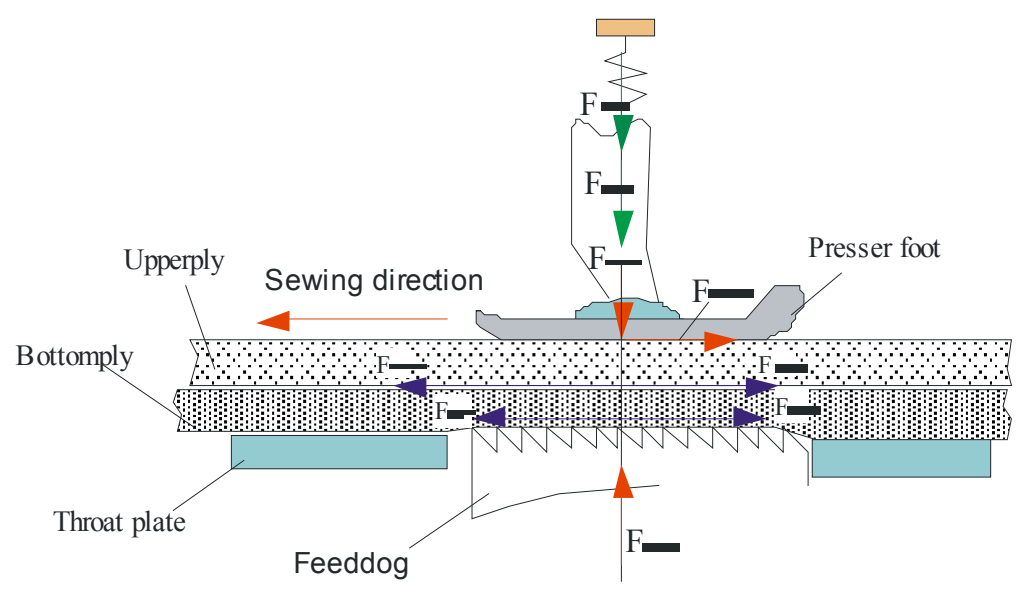

Figure 1. Forces acting on the work piece during the fabric feed with two fabric plies

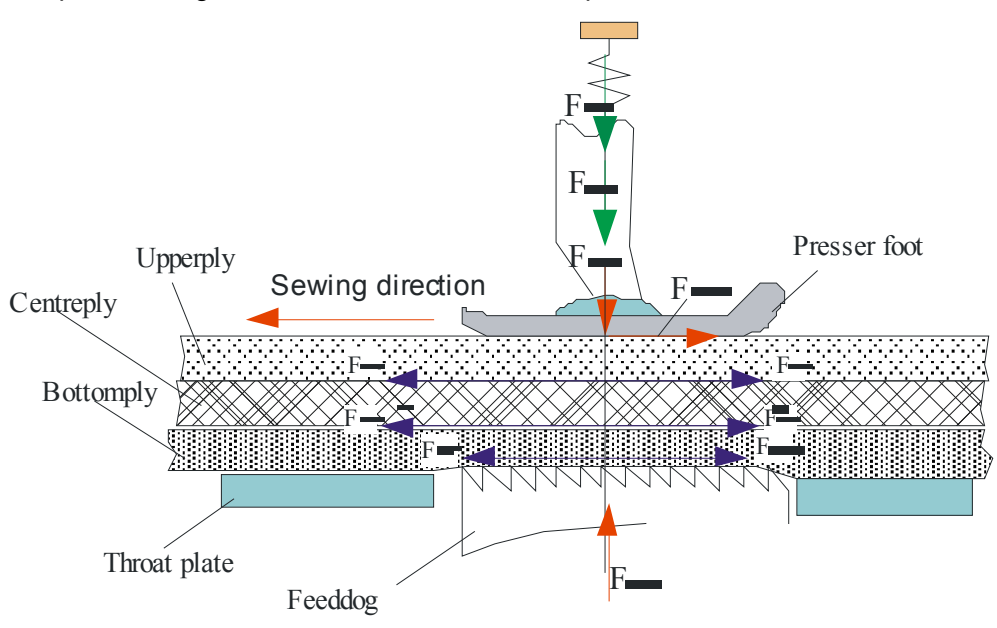

Figure 2. Forces acting on the work piece during the feed of three fabric plies 
of vertical movement serves as the basis for applying the dynamic pressure of the presser foot on the fabric because seam quality depends on this pressure. Figure 3 shows the dynamic model of the fabric-presser foot-spring system [8].

\subsection{Dynamic model of horizontal movement}

The analysis of the horizontal movement of the fabric guided by the pressure of the feed mechanism in the case of sewing two plies of fabric can be roughly modeled by a simplified dynamic model $[9,10]$.

The damping and elasticity of part of the upper ply of the fabric between the previous needle stitch and the position of the next needle stitch is represented by the extent of stiffness $c$ and the shock absorber of constant damping $\beta$. Friction occurs on contact surfaces, and in this case, we have three contact surfaces:

- feed dog-bottom fabric ply, friction coefficient $\mu_{3}$,

- between two fabrics, friction coefficient $\mu_{2}$,

- between the presser foot and the upper fabric, friction coefficient $\mu_{1}$.

\section{Research results}

Table 4 shows the results of the analysis of the research results of vertical and horizontal forces at different sewing speeds through two and three fabric plies. Each type of the examined knit fabric was sewn 20 times.

In the case of sewing the double knit fabric through two plies of fabric using a sewing speed of 3,000 stitches/min, vertical force was higher by $7.91 \%$ in relation to horizontal force. In the case of sewing through two plies of fabric using a sewing speed of 4,000 stitches/min vertical force was higher by $34.7 \%$.

By comparing the forces during sewing with 3,000 and 4,000 stitches/min through two plies of fabric, vertical force showed an increase by $39.5 \%$ at a higher speed, while horizontal force was higher by $14.6 \%$, also at a higher speed. When sewing the double jersey (rib one plus one), through three plies of fabric at a sewing speed of 3,000 stitches/min, vertical force was higher by $33.7 \%$ in relation to horizontal force. When sewing through three plies of fabric at a sewing speed of 4,000 stitches/min, vertical force was higher by $43 \%$. By comparing the force when sewing at a sewing speed of 3,000 and 4,000 stitches/min through three plies of fabric vertical force showed an increase by $25 \%$ at a higher sewing speed, while horizontal force was higher by $14.4 \%$, also at a higher sewing speed.

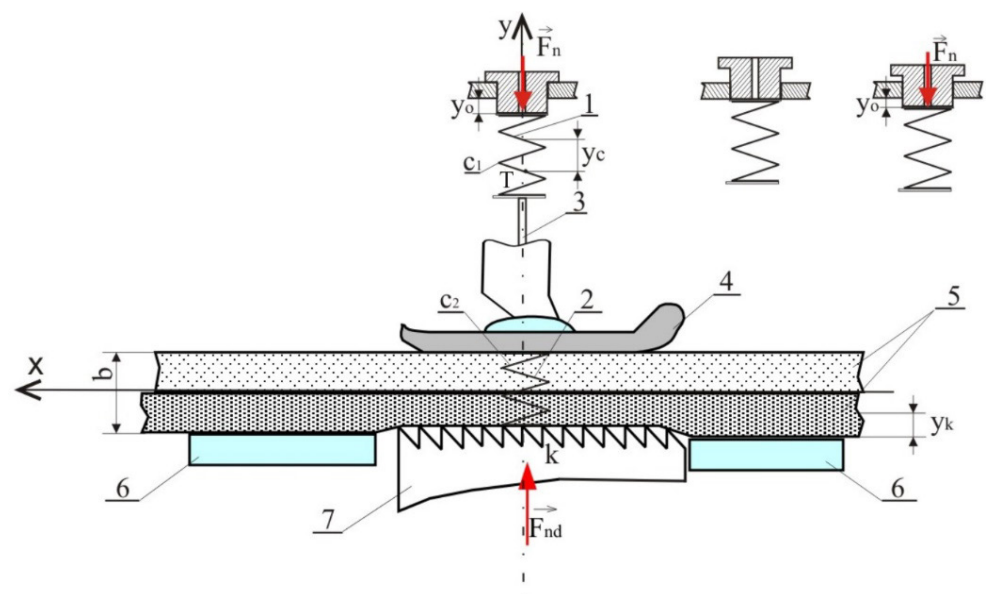

Figure 3. Dynamic model of vertical movement. 1, spring 1; 2, material stiffness ("spring 2"); 3, shaft; 4, presser foot; 5 , textile material; 6, throat plate; 7 , feed dog; G, mass of presser foot, its shaft, and one-third of spring; $c_{1}$, spring stiffness; $c_{2}$, material stiffness; T, center of gravity of presser foot, shaft, and spring; $y_{0}$ - deformation of spring 1 at static pressure; $y_{k}$-deformation of tooth tip $k$ of the center tooth of the feed dog.

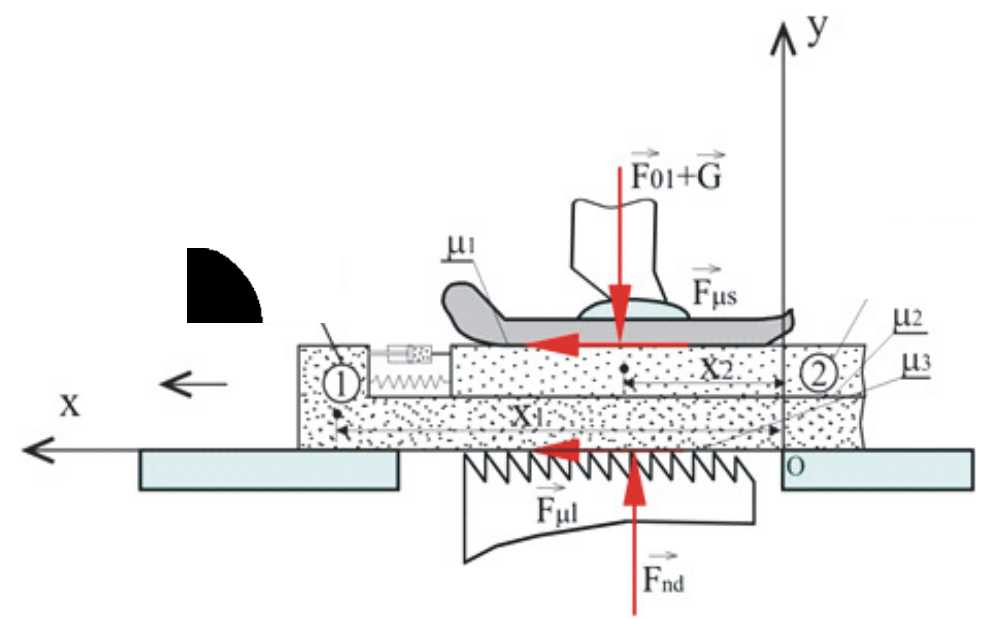

Figure 4. Dynamic model of horizontal movement of material 
Table 4. The results of the analysis of the research results of vertical and horizontal forces

\begin{tabular}{|c|c|c|c|c|c|c|c|c|}
\hline \multirow{2}{*}{$\begin{array}{l}\text { Type of knitted } \\
\text { fabric }\end{array}$} & \multirow{2}{*}{$\begin{array}{l}\text { The number of } \\
\text { plies }\end{array}$} & \multirow{2}{*}{$\begin{array}{l}\text { Sewing speeed } \\
\text { [stitches/min] }\end{array}$} & \multicolumn{3}{|c|}{ Vertical force $[\mathrm{N}]$} & \multicolumn{3}{|c|}{ Horizontal force $[\mathrm{N}]$} \\
\hline & & & $\mathbf{x}$ & SD & $\mathrm{CV} \%$ & $\mathbf{x}$ & SD & $\mathrm{CV} \%$ \\
\hline \multirow{4}{*}{ Double jersey } & \multirow{2}{*}{2 plies } & 3,000 & 2.40 & 0.28 & 11.6 & 2.21 & 0.26 & 11.9 \\
\hline & & 4,000 & 3.97 & 0.73 & 18.5 & 2.59 & 0.25 & 9.5 \\
\hline & \multirow{2}{*}{3 plies } & 3,000 & 3.70 & 0.78 & 21.1 & 2.45 & 0.24 & 9.9 \\
\hline & & 4,000 & 4.96 & 0.68 & 13.8 & 2.83 & 0.23 & 8.2 \\
\hline \multirow{4}{*}{ Interlock } & \multirow{2}{*}{2 plies } & 3,000 & 2.43 & 0.40 & 16.4 & 2.19 & 0.19 & 8.7 \\
\hline & & 4,000 & 3.87 & 0.93 & 23.9 & 2.64 & 0.20 & 7.7 \\
\hline & \multirow{2}{*}{3 plies } & 3,000 & 3.70 & 0.36 & 9.9 & 2.47 & 0.18 & 7.2 \\
\hline & & 4,000 & 4.93 & 0.94 & 19.1 & 2.98 & 0.21 & 7.1 \\
\hline \multirow{4}{*}{ Bleached interlock } & \multirow{2}{*}{2 plies } & 3,000 & 1.87 & 0.22 & 11.8 & 2.33 & 0.30 & 13.0 \\
\hline & & 4,000 & 3.73 & 0.75 & 20.0 & 2.80 & 0.33 & 11.8 \\
\hline & \multirow{2}{*}{3 plies } & 3,000 & 2.41 & 0.30 & 12.5 & 2.61 & 0.26 & 10.1 \\
\hline & & 4,000 & 4.79 & 0.77 & 16.0 & 3.15 & 0.31 & 9.7 \\
\hline
\end{tabular}

In the case of sewing the interlock fabric through two plies of fabric using a sewing speed of 3,000 stitches/min, vertical force was higher by $9.8 \%$ in relation to horizontal force. In the case of sewing through two plies of fabric using a sewing speed of 4,000 stitches/min, vertical force was higher by $31.7 \%$.

By comparing the forces during sewing with 3,000 and 4,000 stitches/min through two plies of fabric, vertical force showed an increase by $37 \%$ at a higher speed, while horizontal force was higher by $17 \%$, also at a higher speed. When sewing the interlock fabric through three plies of fabric at a sewing speed of 3,000 stitches/min, vertical force was higher by $33.2 \%$ in relation to horizontal force. When sewing through three plies of fabric at a sewing speed of 4,000 stitches/min, vertical force was higher by $39.5 \%$. By comparing the force when sewing at a sewing speed of 3,000 and 4,000 stitches/min through three plies of fabric vertical force showed an increase by $25 \%$ at a higher sewing speed, while horizontal force was higher by $17 \%$, also at a higher sewing speed.

In the case of sewing the bleached interlock through two plies of fabric using a sewing speed of 3,000 stitches/min vertical force was smaller by $19 \%$ in relation to horizontal force. In the case of sewing through two plies of fabric using a sewing speed of 4,000 stitches/min vertical force was higher by $25 \%$.

By comparing the forces during sewing with 3,000 and 4,000 stitches/min through 2 plies of fabric vertical force showed an increase by $49.8 \%$ at a higher speed, while horizontal force was higher by $16.8 \%$, also at a higher speed. When sewing the bleached interlock fabric through three plies of fabric at a sewing speed of 3,000 stitches/min, vertical force was smaller by $7.6 \%$ in relation to horizontal force. When sewing through 3 plies of fabric at a sewing speed of 4,000 stitches $/ \mathrm{min}$, vertical force was higher by $34.2 \%$. By comparing the force when sewing at a sewing speed of 3,000 and 4,000 stitches/min through three plies of fabric vertical force showed an increase by $49.7 \%$ at a higher sewing speed, while horizontal force was higher by $17 \%$, also at a higher sewing speed.

The statistical analysis by three-factor variance analysis is shown in Tables 5 and 6 . Vertical and horizontal forces are analyzed using the Kolmogorov-Smirnov normal distribution test. This is a condition for the application of a model of threefactor variance analysis. Tables 5 and 6 show that the influence of the main effects (factors are type of knitting, number of layers, and sewing speed) are statistically significant. Of the possible interactive influences, it is statistically significant only in the case of the type of knitting combined with the speed of sewing and only for the vertical force (Figure 5) [11].

\section{Conclusion}

By analyzing the research results, the following conclusions were achieved:

- Higher values of vertical forces in relation to horizontal forces of the presser foot of the sewing machine were determined for all three types of knit fabrics.

- The values of the investigated forces increased by increasing the number of fabric plies and the sewing speed.

- The values of vertical forces were higher than the values of horizontal forces, except in the case of the bleached interlock knit fabric when sewing 2 and 3 fabric plies at a sewing speed of 3,000 stitches/min.

In the light of the above findings, it is necessary to optimize the above-mentioned parameters analyzed in this study to achieve a high-quality seam on knit wear. The optimal adjustment of the 
Table 5. Results of the analysis of the influence of the type of knitwear, number of layers, and sewing speed on the vertical force (N) with the three-factor model of variance analysis

\begin{tabular}{|c|c|c|c|c|c|}
\hline The source of scattering & $\mathbf{d f}^{\mathbf{a}}$ & $\mathbf{S S}^{b}$ & MS & $F^{d}$ & $\mathbf{p}^{\mathrm{e}}$ \\
\hline Constant & 1 & $3,040.95$ & $3,040.95$ & $7,300.32$ & $<0.001$ \\
\hline $\begin{array}{l}\text { Main effects } \\
\text { Type of knitted fabric (Ty F) }\end{array}$ & 2 & 15.87 & 7.93 & 19.05 & $<0.001$ \\
\hline Number of layers (N L) & 1 & 64.38 & 64.38 & 154.55 & $<0.001$ \\
\hline Sewing speed (S s) & 1 & 158.28 & 158.28 & 379.97 & $<0.001$ \\
\hline $\begin{array}{l}\text { Interaction } \\
\text { Ty } F \times N L\end{array}$ & 2 & 1.71 & 0.85 & 2.05 & 0.131 \\
\hline Ty F $\times$ S s & 2 & 7.51 & 3.75 & 9.01 & $<0.001$ \\
\hline NL×S S & 1 & 0.00 & 0.00 & 0.00 & 0.976 \\
\hline Ty $F \times N L \times S s$ & 2 & 2.05 & 1.03 & 2.47 & 0.087 \\
\hline Random error & 228 & 94.97 & 0.42 & & \\
\hline Total & 239 & 344.76 & & & \\
\hline
\end{tabular}

Table 6. Results of the analysis of the influence of the type of knitwear, number of layers, and sewing speed on the horizontal force (N) with the three-factor model of variance analysis

\begin{tabular}{|l|c|c|c|c|c|}
\hline The source of scattering & $\mathbf{d f}^{\mathbf{a}}$ & $\mathbf{S S}^{\mathbf{b}}$ & $\mathbf{M S}^{\mathbf{c}}$ & $\mathbf{F}^{\mathbf{d}}$ & $\mathbf{p}^{\mathbf{e}}$ \\
\hline Constant & 1 & $1,625.00$ & $1,625.00$ & $25,949.94$ & 14.82 \\
\hline $\begin{array}{l}\text { Main effects } \\
\text { Type of knitted fabric (Ty F) }\end{array}$ & 2 & 1.86 & 0.93 & 79.20 & $<0.001$ \\
\hline Number of layers (N L) & 1 & 4.96 & 4.96 & 197.64 & $<0.001$ \\
\hline Sewing speed (S s) & 1 & 12.38 & 12.38 & 0.54 & 0.581 \\
\hline $\begin{array}{l}\text { Interaction } \\
\text { Ty F } \text { N L }\end{array}$ & 2 & 0.07 & 0.04 & 1.38 & 0.254 \\
\hline Ty F $\times$ S s & 2 & 0.17 & 0.09 & 0.42 & 0.520 \\
\hline N L $\times$ S s & 2 & 0.03 & 0.03 & 0.11 & 0.897 \\
\hline Ty F $\times$ N L $\times$ S s & 228 & 14.28 & 0.07 & & \\
\hline Random error & 239 & 33.75 & & \\
\hline Total & & & & \\
\hline
\end{tabular}
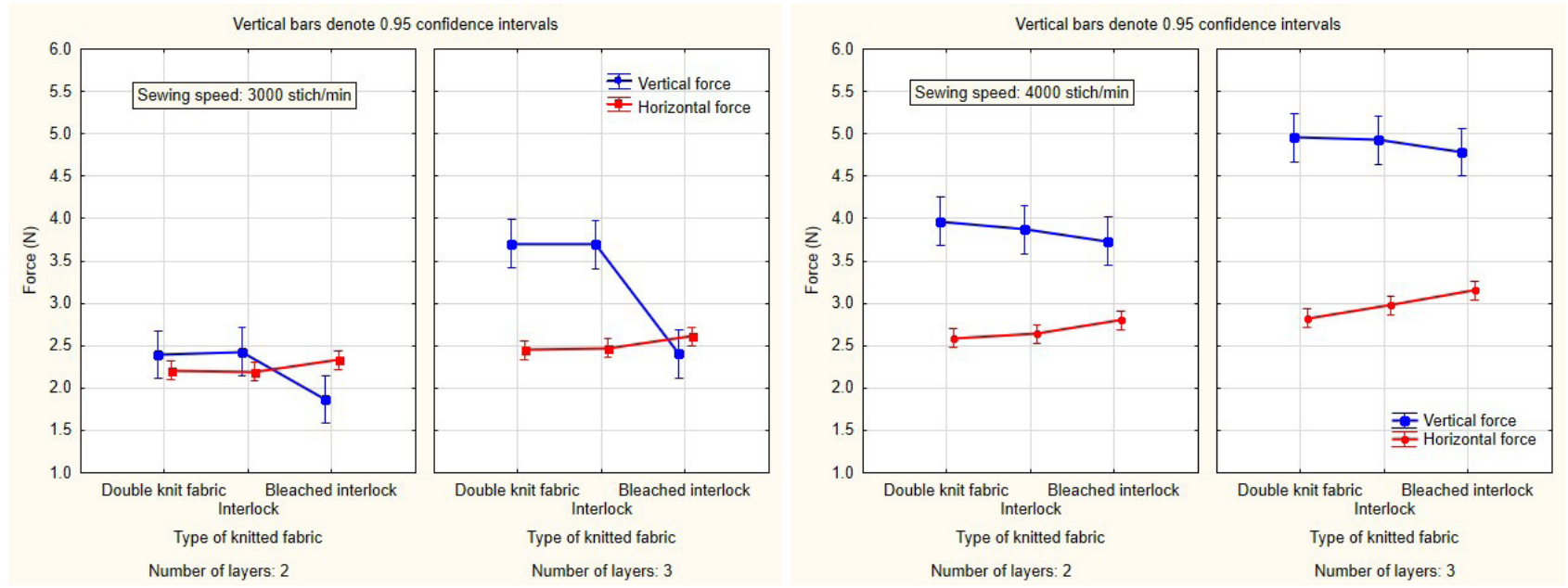

Figure 5. Influence of the main effects: type of knitting, number of layers, and sewing speed 
investigated parameters affects the quality of the seam which is one of the basic prerequisites for a high-quality product.

\section{References}

[1] Bolić. B.: "Prilog analizi utjecajnih parametara na posmik pletiva u procesu šivanja, Zagreb, prosinac 2008.

[2] Ujević D., Rogale D.,. Kartal M, Brlobašić Šajatović B.: Impact of Sewing Needle and Thread on the Technological Process of Sewing Knitwear, Fibres \& Textiles in Eastern Europe, 16, (2008), 4; 85-89, ISSN 1230-3666

[3] Ujević D., Brlobašić Šajatović B., Doležal K., Hrženjak R., Wadsworth, L. C.: Influence of Sewing Needle Penetration Force on the Quality of Knitted Garment, Proceedings of the Beltwide Cotton Conferences 2008, Cotton Utilization: Fabric Chemistry \& Products Symposium, Nashville, Tennessee, USA, 08-11 January 2008, Boyd, S.; Huffman, M.; Richter, D.; Robertson, B. (Ed.), 2008, 1812-1821

[4] Ujević D., Brlobašić Šajatović B., Doležal K., Hrženjak R.: Investigation and Optimization of Specific Technological Sewing Parameters in Knitwear Manufacture, Proceedings of the 9th Autex Conference, 26-28. svibnja 2009., Kadođlu H.; Kumbasar E. P.; Celik P.; Arykan C. O.; Cay A.; Damcy G. (Ed.), Ege University, Department of Textile Engineering, Izmir, Turska, 908-912, ISBN 978-975-483$787-2$
[5] Bühler, G., Dörfler, H., Hemrich, L.: Untersuchungen über das Transportverhalten von Maschenstoffen an der Nähmaschine, Denkendorf, 1996, page 588-683.

[6] Nestler, R. i Arnold, J.: Messtechnische Untersuchungen zum Nadeldurstechkraft-verhalten wahrend des Nahprozesses, Bekleidung und Maschenware, 18 (1979) 3, str. 132-136

[7] E.A.Marakušev: Eksperimentalno-analitička metoda djelovanja valjaka na materijal, Tehnika Kiev, 1976.

[8] Nikolić G., Šomođi Ž., Numerical Dynamic Analysis of Fabric Transport in the Sewing Proceedings of the 14th International DAAAM Symposium, ed. B. Katalinić, Wienna (2003)

[9] Šomođi Ž., Nikolić G.: Dynamic model for estimating friction effect on to the sewing regularity, Book of Proceedings, 2 nd International Textile, Clothing \& Desing Conference, Dubrovnik, Croatia, 3 th-6 th October 2004, 617-623

[10] Robak D.: A model of Fabric Transport in a Sewing Machine Using a Feed Dog Covered with a Suplle Material of Increased Friction, Fibres \& Textiles in Easten Europe, VII-IX., $2002(59,62)$

[11] Pallant J: SPSS: priručnik za preživaljavanje, Potpuni vodič kroz analizu podataka pomoću SPSS-a, prevod 4.izdanja, Mikro knjiga, Beograd, 2011. 